of artificial radioactivity in silver by bombardment with slow neutrons is also demonstrated. The second coach deals with the practical applications of atomic energy, and it starts with a demonstration of the detection of fission in uranium. The gas diffusion, thermal diffusion and electromagnetic methods of isotope separation are all demonstrated on working models. The application of radioactive elements to medicine is illustrated on a film. All experiments are arranged to run automatically, but a member of the Atomic Scientists' Association is in attendance to give additional explanations.

The exhibition was first open to the public in Chester on November 10 . It went from there to Stoke, and its further itinerary includes Manchester, Blackpool, Carlisle, Glasgow, Dundee, Aberdeen, Edinburgh, Newcastle, Middlesbrough, York, Leeds, Sheffield, Derby, Coventry, Nottingham, Leicester, Birmingham, Shrewsbury, Swansea, Bristol, Cardiff, Oxford, Reading and London. Efforts are being made to extend the duration of the exhibition to enable it to visit more places in the south of England. Inquiries about the exhibition should be addressed to Dr. J. Rotblat, Physics Department, University of Liverpool.

\section{Starch Hydrolysis by Polarized Light}

IT has earlier been reported that exposure to polarized light induces hydrolysis of starch both in vitro and in the mesophyll of leaves. Now Dr. Elizabeth S. Semmens (Plant Physiology, 22, 270 278 ; 1947) describes experiments on the effect of polarized light on the starch content of stomatal guard cells. With a variety of plants and using both detached strips of epidermis and whole leaves attached to the parent plants, polarized light induces starch hydrolysis in the guard cells of the stomata; and this hydrolysis is accompanied by stomatal opening. Although in some cases the periods of exposure that preceded the observations were somewhat prolonged, these effects were also found when the period of exposure was only a few hours. With polarized direct sunlight the starch hydrolysis proceeded more vigorously, and bursting of the guard cells sometimes occurred. Although it appears likely that these observations, regarded as preliminary by the author, may, when extended, make a contribution to our knowledge of the vexed problem of stomatal mechanisms, their precise significance is at present difficult to assess.

\section{Dominion Observatory, Wellington}

THe annual report for the year 1944 of the Dominion Observatory, Wellington, N.Z., shows that there was a general decline in seismic activity as compared with previous years. There was some concentration of activity south of Lake Taupo, but the intensity anywhere did not exceed V + on the modified Mercalli scale and the shocks were not destructive. Sixty-one tremors were felt in the North Island, forty in the South Island and six in both. The Jaggar seismograph at Hastings was in operation again by July and the seismographs at Auckland, Arapuni, Tuai, New Plymouth, Bunnythorpe, Wellington, Takaka, Kaimata, Christchurch and Monowai were recording throughout the year. The death occurred on May 24, 1944, of Mr. A. W. Burrell of Stratford, who for some time operated a Jaggar seismograph for the Department of Scientific and Industrial Research in the Dominion.

\section{National Museums of Ceylon}

THIs Director's report for 1945 (published 1946) on the national museums of Ceylon includes the Colombo, Kandy, Ratnapura, Jaffna and Navala Museums. All have suffered, in varying degrees, the difficulties associated with requisition, evacuation, or other wartime contingency, and in some cases results have been serious. The present report, however, shows that these institutions are now returning to their normal peace-time activities. From the Colombo Museum, for example, it is reported that the important work on the Museum's collections in relation to Ceylon's extinct mammals, living fauna, prehistory and certain antiquities, was resumed and the results published during the year. Damage and losses are still being assessed in this Museum, and the Jaffna Museum reports that only a very small part of the Twynam collections (stored in the Old Dutch Church) will be fit for exhibition again. Lists of acquisitions in respect of each museum are given in detail.

\section{Anthropological and Archæological Work in India}

THE Journal of the Indian Anthropological Institute, vol. 1 (New Series), 1945, contains a number of interesting articles. Desiccation of Asia and its effect on human occupation is discussed by the late Sir Aurel Stein. Colonel Gordon surveys ancient Gandhara, and also describes some rock engravings and microliths in the Bangalore area. Colonel Gordon has long ago shown that most of the rock-shelter paintings and the rock carvings in India cannot be of any considerable antiquity. Nevertheless, such finds are of great interest, even if not very ancient. There are also papers on megalithic monuments of southern India by A. Aiyappan, and on Gond exogamy by M. P. Buradkar.

\section{French Scientific Library in London}

A small French scientific library is being built up at the Institut Francais du Royaume-Uni, London. Both books and periodicals can be borrowed by post. In addition, microfilms of articles appearing in periodicals not available in the library can be obtained. from France. These can either be consulted in the library, where a microfilm reader has been installed, or borrowed by post. All the library services are provided free. A catalogue of the books and periodicals available can be obtained from the Librarian, Scientific Library, Institut Français du Royaume-Uni, Queensberry Place, South Kensington, London, S.W.7.

\section{Institution of Civil Engineers : Council for 1947-48}

THE Council for 1947-48 of the Institution of Civil Engineers is as follows: President: Sir Roger Hetherington; Vice-Presidents : Sir Reginald Stradling, Sir Jonathan Davidson, W. H. Morgan, V. A. M. Robertson; Other Members of Council : H. E. Aldington, Sir Stanley Angwin, Prof. J. F. Baker, G. Baxter, D. B. Brow (India), W. S. Cameron, F. M. Corkill (New Zealand), H. F. Cronin, Sir Arthur Dean (India), Dr. W. H. Glanville, A. Gray (Canada), Dr. E. J. Hamlin (South Africa), A. C. Hartley, G. H. Humphreys, Sir Claude Inglis, L. Leighton, H. J. B. Manzoni, M. S. Moore (Australia), Prof. A. J. S. Pippard, A. S. Quartermaine, J. C. L. Train, W. K. Wallace, Sir Arthur Whitaker; Past-Presidents : Dr. D. Anderson, F. E. Wentworth-Sheilds, Sir Peirson Frank, Sir William Halcrow ; Secretary: E. Graham Clark. 